\title{
Economic cooperation and trade potential of Indian energy sector products between India and BCM region
}

\author{
Kallal Banerjee $^{1, *}$, Depankar Dey ${ }^{2}$ \\ ${ }^{\mathbf{1}}$ Assistant Professor, F. E. I. M, Kolkata, West Bengal, ${ }^{2}$ Visiting Professor \& PhD. Guide, Dept. of Business Management, \\ Calcutta University, Kolkata, West Bengal, India \\ *Corresponding Author: \\ Email: kallalban2@rediffmail.com
}

\begin{abstract}
South \& East Asia has become a critical and important part of the world trading system since last couple of decades. It has also emerged as the world's fastest-growing economy. As a geographically connected region, the BCIM Economic Corridor (EC) is expected to ease the flow of goods between two of the largest and oldest economies of the globe namely India and China. It will also provide greater economic resources to the burgeoning markets of Bangladesh and Myanmar. The primary objectives of the study are to identify major tradable products of the energy sector of India and cluster them as per their trade potential. In this study, the scope of energy sector has been kept confined to products and equipment directly associated with energy access. Energy security has been kept outside the purview of this present study. Using 6-digit Harmonized System (HS-codes) of classification for both renewable and non-renewable energy, a list of 270 products and major equipment, associated with renewable and non-renewable energy sector, have been identified for preliminary analysis of India's trade potential of energy sector products in the BCIM region. Various clusters of products and equipment associated with energy sector have been formed. The clusters have been made on the basis of seven different parameters which are commonly used for analyzing trade date. For each product, values for these seven parameters have been estimated using past trade data (2009-13). Primarily, WITS data has been used. And to understand intra-industry trade (IIT), the Grubel-Lloyd index has been used.FK index has been used to understand the trade creation and trade diversion potential of the trading partners. SMART package has been used to estimate welfare gains for BCIM member countries
\end{abstract}

Keywords: RCA, IIT, TCI, BCIM, SMART, GLI, RTA, FKI, RCDA, SSI.

\section{Introduction}

South \& East Asia has become a critical and important part of the world trading system since last couple of decades and it has emerged as the world's fastest-growing economy. The 'Look East Policy (LEP)', initiated in 1991 by the government of India, has marked a strategic shift in India's perspective of the world. The Centre for Policy Dialogue (CPD) in Bangladesh, Yunnan Academy of Social Sciences (YASS) in Kunming, China, the Centre for Policy Research (CPR) in India and the Ministry of Border Trade of Myanmar were the pioneering institutions which agreed, in 1999, to launch the BCIM (Bangladesh China India Myanmar) initiative which was initially called as the 'Kunming initiative'. It is basically a Track II (non-government) Regional Trade Facilitation Initiative (RTFI) for the betterment of economic collaboration within this region. Total geographical area of BCIM is 13.7 million sqkms (9\% of the global area) with a population estimated at 3.05 billion consisting roughly $40 \%$ of world population. The GDP of these four countries is estimated at US \$ 6.2 trillion, which is around $10 \%$ of total GDP of world. So BCIM initiative is most crucial from the geographical and political view point of India and it is integral to the development of northeast part of India. Geographically, BCIM as a whole faces the world's greatest bay, the Bay of Bengal. As a geographically connected region, the BCIM Economic Corridor (EC) is expected to ease the flow of goods between two of the world's largest economies, namely, India and China.

\section{Literature Review}

Bhattacharyya (2011) in his book 'Energy Economics: Concepts, Issues Markets and Governance', deals with various factors which makes the energy sector relatively complex and highly technical in nature. Hubler and Keller (2009) in their paper, 'Energy saving via FDI: empirical evidence from developing countries' highlighted the influence of FDI inflows on energy intensities for developing countries. Zheng Zhihua (2012) in his paper 'Myanmar as an important pivot for China's Indian ocean strategy' highlighted that political stability and economic development of Myanmar would have an important impact on border security and environment of Southwestern China.M. Rahmatullah (2011) in his paper 'strengthening regional transport connectivity among BCIM countries' reviewed the current state of transport connectivity and highlighted the sectors which needed to be strengthened and improved to establish proper transport connectivity among BCIM countries. Mahendra P. $\operatorname{Lama}(2010)$ in his paper 'cooperation in the BCIM region: rethinking opportunities and newer approaches' states that BCIM members countries should have two way approach in order to initiate the energy cooperation ventures. One is to provide the policy and institutional framework and 
other is to cooperate in power trade. Rahman (2013) considers that the cross-border trade in energy, setting up of regional oil and gas, electricity transmission grids and distribution facilities could generate significant gains for the people of the region. Veena Jha (2009) in her study titled 'Trade Flows, Barriers and Market Drivers in Renewable Energy Supply Goods' deals essentially with trade flows and barriers to commercially-available renewable energy generation technologies and their associated goods. It also identifies and examines the role of various market and trade drivers, including tariffs in the uptake of these technologies. Rahman (2007) used different trade indices, such as Regional Orientation Index (RTOI), Grubel-Llyod Index (GLI) and Trade Intensity Index (TII), to suggest that huge potential existed for trade and investment complementarities among BCIM countries.

\section{Research Problem}

Energy cooperation was one of the major areas of discussions in the 11th BCIM meet held in Dhaka during February 2013. The BCIM region is remarkably rich in natural resources, including oil and gas, water and coal. Unfortunately, these resources are not evenly distributed within and across the boundaries. Some bilateral initiatives are already in operation in this respect (e.g. Bangladesh's import of electricity from India; import of gas from Myanmar by China). Being a major economy of BCIM, India's energy sector is expected to play an important role in this large market.

\section{Hypothesis}

There will not be much welfare gain for India and other BCIM member countries through free trade of energy sector products in the region.

\section{Research Objectives}

The primary objectives of the study are to identify major tradable products of the energy sector of India and cluster them as per their trade potential. To achieve these objectives we shall focus our study on the following topics

(i) Define the scope of energy sector and identify the tradable products which come under its purview.

(ii) Analyze five years' (2009-13) export and import trends of these products

(iii) Identify Indian products having comparative advantage vis-a-vis BCM region

(iv) Divide tradable energy sector products into different clusters based on their trade potential and suggest appropriate business strategy to boost India's export to BCM region.

(v) Estimate the welfare gains for BCIM member countries at a zero tariff regime.

\section{Materials and Method}

The following methodologies have been adopted in this study.

a) For defining the scope of energy sector and to prepare the list of tradable products associated with it, published literature on this topic has been used.

b) And to understand India's trade potential of these energy sector products and to suggest appropriate strategy,

(i) Energy sector products have been segregated into four categories and two clusters. These categories and clusters have been made based on different parameters, which are commonly used to analyze trade date.

(ii) For each product, values for the parameters have been estimated using past trade data (2009-13). Primarily, WITS data (provided by the World Bank) has been used. To understand intra-industry trade (IIT), the Grubel-Lloyd index has been used. FK index has been used to understand the trade creation and trade diversion potential of the trading partners.

c) SMART package has been used to estimate welfare gains for BCIM member countries.

Structure of the paper: The paper is divided into six sections.

Section 1 defines the scope of energy sector and identifies major tradable products associated with energy sector.

Section 2 analyzes five years' (2009-13) export and import trends of the energy sector products of India. Based on RCA values, this section segregates the products into four broad categories namely three stars $(* * *)$, two stars $(* *)$, one star $(*)$ and no star.

Section 3 deals with other parameters and calculates their values to address the third objective of this study. This section analyzes the comparative advantage/disadvantage of different Indian products vis-a -vis BCM region. It also compares RCA values of Indian and Chinese products for 2013, and the applied tariffs (AHS) imposed by India and China on their imported products.

In section 4 identifies clusters, based on the following criteria,

a. Cluster 1 (C1): is a cluster of products which have $\mathrm{RCA}<1$ and ROI $>1$. In short run one can gain from these products' exports due to 'trade diversion' but in long run these products may not survive the competition.

b. Cluster 2 (C2): This cluster comprises of products which have RCA $>1$ and $\mathrm{ROI}<1$. These products have 'scope for trade creation'.

In section, 5 author determined potentiality of energy sector products among BCIM region.

In section, 6 author evaluated trade creation and diversion through gravity model. 


\section{Section 1:}

Defining the energy sector and scope of this study

The energy sector is complex. Each industry of the sector has its own specific features, which require special attention. At the global level, three major influences could be observed: (a) energy trade, (b) international institutional influences (of WTO, IMF, the World Bank, UN et al) and (c) interaction among countries- co-operation, competition and conflicts. This paper will focus only on the first and third influences, as above, on Indian energy sector. As the energy sector is composed of different industries/sub sectors, each with different technical and economic characteristics, its spread is very wide. For example, it uses inputs from various other sectors like iron and steel, machine tools, transports, electronics et al. Energy is also a key input for most of these sectors. Moreover, the generation and distribution process, of the renewable and nonrenewable conventional energy, differs substantially. In this study, the scope of energy sector has been kept confined to products and equipment directly associated with energy access i,e (a) energy products itself, say, petroleum, coal, natural gas et al. and (b) critical inputs (say uranium ore) and equipment needed to generate, transmit and distribute energy- both renewable and non renewable types.

\section{Major tradable products and equipment associated with energy sector}

Using 6-digit Harmonized System (HS-codes) of classification for both renewable and non-renewable energy, a list of 270 products and major equipment associated with renewable and nonrenewable energy sector, have been identified for preliminary analysis of trade in energy products among BCIM countries. However Electrical Energy (HS code 271600), though mentioned in the list, has not been taken into consideration for analysis as this paper focuses only on equipment and products related to energy sector only. The products related to renewable energy sources (RES) have been included from the lists prepared by Jha (2009) and Exim Bank (2011). Though Jha, in her list titled 'HS Codes for Renewable Energy Technologies and Components', had identified more than 60 odd items, in our study we have used 53 items as identified by the Exim Bank list titled, '6-digit HS Codes for Goods related to New Renewable Energy Sector'(actually this is a sub set of Jha's list). For nonrenewable sector, the items have been identified using ITC and WITS database.

\section{Section 2}

Overall trade balance of energy sector between India and $B C M$ region: -

In this section, we have examined the trade balance between India and BCM countries. Trade balance in different years has been calculated based on all energy products India exported to and imported from the region i.e. Bangladesh, China and Myanmar. we observe that India's aggregate trade balance in all energy sector products with BCM region were negative in all the five years and the trade gap increased during 2009- 2011. Since 2012onwards, the trade balance had improved marginally, though those remained negative. From the energy sector trade balance it is clear that India imported more energy sector products (than it exported) from $\mathrm{BCM}$ region. India's export to $\mathrm{BCM}$ region has increased by 2.6 times during 2009-13. Though its export share to China has increased during this period, its share of export to Bangladesh has declined. During the same period, the number of exported products (6digit code) had increased from 201 to 234. India's import from BCM during 2009-13 had increased by 1.4 times and almost all the imports were from China. However, import dependence on China declined marginally during this period. The total number of imported products (6digit code) had remained same at 248 in 2009 and 2013.

\section{Observation based on RCA values of the energy sector products of India:- \\ RCA values of Indian energy sector products have} been calculated for the year 2009 and 2013 and four lists have been generated.

a) List1 contains a list of 154 products whose RCA values have improved between 2009 and 2013. It shows that in a gap of five years, competitive advantage of over $56 \%$ of the identified products has increased. These products have been marked with a single star "“* ".

b) List 2 contains a list of 64 products $(23.7 \%$ of the 270 identified products) whose RCA values in 2013 were greater than equal to one. These products are marked with double stars "*** ".

c) List 3 has only 31 products whose RCA values in 2013 were greater than one and between 2009 and 2013 the RCA values had improved by more than 0.50 . These products have been marked with triple stars ${ }^{\text {"***** “. }}$

d) List 4 contains 116 products whose RCA values have deteriorated between 2009 and 2013.

\section{Observation based on export trend:}

We have analyzed the export trend, between 2009 and 2013, of the identified products and from these time series data calculated the trend i.e. ' $b$ ' values of these products. About 191 products (nearly $70 \%$ of the identified products) whose ' $b$ ' values or slopes of the export curves between 2009 and 2013 were positive. 43 products whose ' $b$ ' values or slope of the export curve during the same period were negative.

\section{Section 3}

Observations based on comparison of RCA values among BCIM member countries: 
We compared the RCA values (2013), of energy sector products for BCIM and identified product wise highest RCA values among the member countries.

a. RCA values (2013) of Indian products $>1$ and also> RCA of corresponding Chinese products: - 52 such products come under this category. As India's competitive advantage is higher than that of China for these 52 products, ideally the trade balance for these products should be positive, at least, for 2013. Interestingly, out of the five years' trade balance (2009-13) we have analyzed, India's trade balances vis-à-vis BCM were negative in three years and were positive in two years $(2011,2013)$ only. It is also very interesting to note that out of these 52 products, India exported 47 items to BCM and imported 50 such products from that region, in2013. Author evaluates India's trade balance with China for these 52 products. Of the five years' (2009-13) trade balance chart we have analyzed, the trade balances were negative in three years and were positive in two years only. We have also identified the number of products India exported to China and simultaneously identified the number of products India imported from China during that time. It is also very remarkable to note that out of these 52 products, India exported 37 items to China and imported 49 such products from that country in 2013. We observe that the number of products India exported to China was significantly less than it exported to $\mathrm{BCM}$ though number of products India imported from both BCM and China were more or less same. It clearly indicates the dominance of the Chinese products in BCM region. Secondly simultaneous import and export of same product within BCIM countries indicates the possibility of high intra-farm transfers among subsidiaries of multinational corporations. It could be due to logistic reasons also.

b. RCA values (2013) of Chinese energy products $>1$ and also> RCA of corresponding Indian energy products: 90 such products belong to this group and China's trade balance (2009-13) for these 90 products was positive in all the five years, indicating a consistent strategic initiative taken by Chinese policy makers. China's trade balance with India for these 90 products of the five years' (200913) data we have analyzed, the trade balances were positive in all the years. We have also identified the number of energy products China exported to BIM and India. These examinations have also identified the number of energy products China had imported from BIM and India during that period. Author observes that the numbers of products China exported to and imported from BIM and India, in 2013, was more or less same. Out of these 90 identified products, in that particular year, China exported 89 and 87 products to BIM and
India respectively and corresponding numbers for imports were 58.

\section{Intra -Industry Trade (IIT):}

The sectorial intra-industry trade (IIT) is a measure of the degree to which trade in a particular sector represents intra-industry trade (based on scale economies and/or market structure). The index ranges from 0 to 1 , with zero indicating pure inter-industry trade, and one indicating pure intra-industry trade. Grubel-Lloyd index indicate the extent of IIT for 270 energy sector products. The intra-industry trade between India and BCM, though not very significant till now, its importance is growing steadily. It also indicates that between India and China, inter industry trade for energy sector products are more important (GLI very close to 0 ) than intra industry trade. And author suggests that, unlike India, China basically relied on inter industry trade with BIM during the period (2009-13) of the study.

\section{Applied tariff imposed by China}

The simple average tariff imposed by China on those Indian energy sector products whose RCA were $>1$ and enjoyed higher RCA than corresponding Chinese products in 2013. Out of 52 such products, India exported only 37 products to China in that particular year. This highlights that India could not exploit the export potential for its remaining 15 products which already enjoyed comparative advantages over corresponding Chinese products. There could be various reasons for this. Apart from insufficient strategic endeavor from Indian side, lack of market access due to various tariff and non-tariff barriers imposed by China could be other important reasons. The average tariff imposed by China on 30 products ranged between 0-40 percent. The weighted average tariff was $7.1 \%$. Though the average tariff does not look that high but China has imposed selectively very high tariff ranging from $14 \%$ to $18 \%$ on few products. Remaining 15 energy products, on which India already enjoyed comparative advantage over corresponding Chinese products, China did not import those products from India.

Now author analyzed the simple average tariff imposed by India on those Chinese energy sector products whose RCA were $>1$ and enjoyed higher RCA than corresponding Indian products in 2013. Out of 90 such products, China exported 83 products to India in that particular year. This highlights that China could exploit the export potential for over $90 \%$ of its energy sector products which enjoyed comparative advantages over corresponding Indian products. Unlike China, India's tariff structure was very simple. It ranged between $0-10 \%$ and the weighted simple average tariff was $6.8 \%$ only.

Author prepared consolidated values of 270 energy sector products' export share to BCM w.r.t world, 5 
years (2009-13) export trend values and RCA, RSCA, ROI, RTA, TII, TCI (2013) values.TCI values between India and $\mathrm{BCM}$ are greater than one. Therefore, both the countries are natural trading partners in the sense that what one country exports overlaps with what the other country imports. From the TCI values, it is clear that formation of a regional trade agreement on energy products among India and BCM countries is justified. Value of TII among majority energy products between India and BCM countries are close to zero, which indicates energy trade, particularly export is very low; though on some products India has positive RSCA values.

\section{Section 4}

In addition to the various categories of products, as identified in Section2, 270 products have been segregated into two different clusters namely Trade Diversion Cluster (C1) and Trade Creation Cluster (C2) Trade Diversion: Trade diversion means trade is being diverted from more efficient exporter to less efficient one by forming FTA among those regional trading blocs. The concept of trade diversion is very much related to patterns of comparative advantage and regional orientation. The situations where regional integration (ROI $>1)$ is potentially harmful for the global economy occur when efficient producers located outside the integrating region lose market shares to less efficient regional producers $(\mathrm{RCA}<1)$ with privileged access to the regional market.

Cluster 1: C1is a cluster of products, which have RCA $<1$ and ROI $>1$ (2013). This Cluster is not sustainable in long run. It is a vulnerable cluster. In short run one can gain from these products' exports due to 'trade diversion' but in long run these products may not survive the competition. $\mathrm{C} 1$ is a trade diversion cluster. 56 products out of 270 products belong to this cluster. Analysis indicates that the trade balance figures for this cluster were negative for all the five years of our study. Negative trade balance had reached its highest level in 2012.Negative trade balance was least in 2013. In our analysis, we have examined the list of products, where RCA of India is less than one but regional orientation index (ROI) among BCM is greater than one. Author evaluates that trade diversion has mainly occurred between India and Bangladesh. Very low value (almost close to zero) of Finger-Kreinin (FK) index justifies the same observation. Analysis indicates that the structure of trade between India and Bangladesh was moving closer to VIIT (Vertical Intra Industry Trade)-indicating trade diversion. SAARC Framework Agreement for Energy Cooperation could be one of the possible reasons of diversion.

Trade Creation and Welfare gains: Trade creation takes place when domestic consumers in member countries import more goods from other members. Trade creation refers to the increase in economic welfare from joining a free trade area or a customs union. Trade creation will occur when there is a reduction in tariff barriers, which lead to an increase in consumer surplus and economic welfare.

Cluster 2: C2 is a cluster of products, which have good export potential, but the potential has not been exploited properly. There exists opportunity or scope for trade creation. Products of this cluster have RCA > 1but Regional Orientation Index (ROI) between India and BCM region is < 1 (2013). 44 products out of 270 products belong to this cluster. Author projected that the trade balance figures of the energy products of this cluster. The negative trade balance increased in 2010 compared to the previous year and it entered in the positive zone in 2011.Wide fluctuations are observed thereafter. From analysis of country specific data on trade creation, trade diversion and welfare gains for these 44 products. These have been estimated at $0 \%$, $5 \%$ and $10 \%$ tariff across BCIM. Analysis summarizes indicates that, while there is scope for trade creation for 44 identified Indian energy products (C2) due to reduced tariff, scope of trade diversification is also very high. The welfare gain is not that substantial. At a reduced tariff, trade creation will be significant vis $-\mathrm{a}$ vis China.

Author identifies 56 Chinese energy sector products whose RCA values are $>1$ and ROI b/w China vs $\mathrm{BIM}<1$. Analysis contains data on trade creation, diversion and welfare creation of China (56 energy products whose $\mathrm{RCA}>1$ and $\mathrm{ROI}<1$ ) with India, Bangladesh, Myanmar at different tariff of $0 \%, 5 \%$, $10 \%$. In case of China, trade creation and welfare gains are substantial higher than India at reduced tariff rates.

But our analysis clearly indicate that India has reached $53.8 \%$ of its total potential of welfare gains at zero tariff rate compared to China's figure of $24.4 \%$ in 270 products.

\section{Section 5 \\ Potential tradable energy products determination in BCIM region.}

We divide entire calculation in two basic primary methods namely Static and Dynamic to determining potential energy products among BCIM regions. In static method, we mainly concentrated RCA, RCDA and Bilateral RCA values.

In first phase, we take combinations of two countries namely India and China, India and Bangladesh and India and Myanmar among BCIM regions to evaluate India energy products potential among BCIM region. List 1 shows us those products whose RCA of India $>1$ and China's RCAD>1 in 2013.

Static Method for BCIM region
India vs. China
\begin{tabular}{|l|l|}
\hline & China RCDA>1 \\
\hline India RCA $>1$ & Products mention in list 1 \\
\hline
\end{tabular}


Products in List 1: Products like Oils \& other products of the distillation of high temp. coal tar; similar products in which the weight of the aromatic constituents exceeds that of the non-aromatic constituents, distilling/rectifying plant whether/not electrically heated, automatic circuit breakers, optical fibres bundles \& cables, fuses for voltage etc. India has potentialities for china's market.

India vs. Bangladesh: List 2 shows us those products whose RCA of India $>1$ and Bangladesh's RCDA $>1$ in 2013. List 3 shows us those products where India RCA $>1$ and Bilateral RCA between India and Bangladesh $>1$ and Bangladesh's RCDA $>1$. The following table shows this result.

\begin{tabular}{|l|l|}
\hline & Bangladesh RCDA>1 \\
\hline India RCA $>1$ & Product mentioned in List 2 \\
\hline $\begin{array}{l}\text { India RCA }>1 \\
\text { and BLRCA }>1\end{array}$ & Product mentioned in List 3 \\
\hline
\end{tabular}

Products mentioned in list 2: Products like light petroleum oils \& preparations, line pipe of a kind used for oil/gas pipelines, Containers for compressed/liquefied gas ,vapour generating boilers including hybrid boilers, Condensers for steam/other vapour power units, liquid dielectric transformers, electrical capacitors, automatic circuit breakers, electric conductors, electrical insulators etc. India has potentiality in Bangladesh markets.

Products mentioned in List 3: India tries to concentrate on products like, towers \& lattice masts of iron/steel, containers for compressed/liquefied gas, water tube boilers with a steam production $>45 \mathrm{t}$ per hour, steam turbines $\&$ other vapour turbines, electric generating sets with C-I internal combustion piston engines, electric conductors, electrical insulators etc. for Bangladesh market.

India vs. Myanmar: Here List 4 shows us those products whose RCA of India $>1$ and Myanmar's RCDA $>1$ in 2013. List 5 shows us those products where India RCA $>1$ and Bilateral RCA between India and Myanmar $>1$ and Myanmar's RCDA $>1$. The following table shows this result.

\begin{tabular}{|l|l|}
\hline & Myanmar RCDA>1 \\
\hline India RCA $>1$ & Products mentioned in List 4 \\
\hline $\begin{array}{l}\text { India RCA }>1 \\
\text { and BLRCA }>1\end{array}$ & Products mentioned in List 5 \\
\hline
\end{tabular}

Product mentioned in List 4: Different Products like Petroleum oils obtained from bituminous minerals, electrical insulators, liquid dielectric transformers, producer gas/water gas generators, steam turbines \& other vapour turbines, towers \& lattice masts of iron/steel, line pipe of a kind used for oil/gas pipelines, concrete pumps, self-propelled mechanical shovels, excavators \& shovel loaders, electric conductors, electrical insulators, automatic circuit breakers for a voltage of $<72.5 \mathrm{kV}$, Liquid dielectric transformers, fuses etc India should focus on Myanmar market.

Product mentioned in List 5: Out of above products, Products like Containers for compressed/liquefied gas, Self-propelled mechanical shovels, excavators \& shovel loaders, electric conductors etc. India has much potentiality in Myanmar's market.

\section{Dynamic Method}

In dynamic method, we mainly concentrated on shift share method. Here we considered two regions India and BCM over period of 2009 to 2013. List 6 shows us those product where India's export shift share to rest of world is greater than zero over the years and BCM import shift share from rest of world $>0$. List 7 shows us India's export shift share to BCM regions is greater than zero over the years and BCM import shift share from rest of world $>0$.

India vs. BCM
\begin{tabular}{|l|l|}
\hline & $\begin{array}{l}\text { BCM Import Shift share } \\
\text { from rest of world }>0\end{array}$ \\
\hline $\begin{array}{l}\text { India Export shift } \\
\text { share to rest of } \\
\text { world }>0\end{array}$ & Products mentioned in List 6 \\
\hline $\begin{array}{l}\text { India Export shift } \\
\text { share to BCM }>0\end{array}$ & Products mentioned in List 7 \\
\hline
\end{tabular}

Products mention in List 6: line pipe of a kind used for oil/gas transport, pneumatic power engines \& motors, continuous-action elevators \& conveyors, oil pressure lamps, solar lanterns or lamps etc. both India's export shift share and BCM import shift share are higher and in this product India have competitive advantage to export to BCM as well as rest of world.

Products mentioned in List 7: indicates products like line pipe of a kind used for oil/gas transport, central heating boilers, liquid dielectric transformers, continuous-action elevators \& conveyors etc. India's export potential is higher to $\mathrm{BCM}$ region as $\mathrm{BCM}$ import shift share is also higher.

\section{Section 6}

Gravity Model analysis: Gravity equations, to capture separately the trade diversion and the trade creation effects, in BCIM regions have been constructed based on 2013 trade data. Notations used in the equations: $E_{i j}$ is the export from country $i$ to country $j$ in energy products, $D_{i j}$ the bilateral distance, $Y_{i}$ is the GDP level of the exporter country, $\mathrm{Y}_{\mathrm{j}}$ is the GDP level of the importer country. $\mathrm{CPI}_{\mathrm{i}} \mathrm{is} \mathrm{CPI}$ of exporter country and $\mathrm{CPI}_{\mathrm{j}}$ is CPI of importer country. $\mathrm{POH}_{\mathrm{i}}$ and $\mathrm{POH}_{\mathrm{j}}$ are population of home and partner country respectively. $\mathrm{PCH}_{\mathrm{i}}$ and $\mathrm{PCP}_{\mathrm{j}}$ is per capita home and partner country respectively. $\mathrm{CL}_{\mathrm{ij}}$ and $\mathrm{CC}_{\mathrm{ij}}$ are common language and common colony between two countries. It takes the value 1 if both country pair ij have common language and colony otherwise value is 0 . RTATC is the dummy 
variable whose value is 1 if the country $i$ and $j$ are members of the RTA. RTATD takes the value 1 if only one of the country pair ij is a member of the RTA.

$\operatorname{Ln}\left(E_{i j}\right)=\infty_{i j}+\beta_{1} \ln \left(Y_{i}\right)+\beta_{2} \ln \left(Y_{j}\right)+\beta_{3} \ln \left(\mathrm{CPI}_{\mathrm{i}}\right)+\beta_{4} \ln$ $\left(D_{\mathrm{ij}}\right)+\beta_{\text {BCIMTC }}$ RTATC $_{\text {BCIM }}+\beta_{\text {BCIMTD }}$ RTATD $_{\text {BCIM }}+\epsilon_{\mathrm{ij}}$ -gravity eq no (i) Coefficient of $Y_{i}(1.464), Y_{j}(.848)$ and $D_{i j}(-1.684)$ are significant at $5 \%$ level. However, negative insignificant coefficients of BCIMTC -1.364 and significant BCIMTD -0.602 indicate that BCIM regional bloc is unlikely to increase/create their trade between member countries and trade is being diverted within the region. Since the number of member countries in BCIM is very limited, regression suffers from insufficient information.

\section{Concluding observations}

This study has grouped 270 energy sector products into different categories, using various trade parameters like RCA, ROI etc, to help Indian policy makers to understand the actual trade potential of these products in the BCIM region. In the proposed BCIM free trade zone (at $0 \%$ rate of tariff across the region), China, India and Bangladesh are likely to gain in terms of trade creation and welfare. Myanmar's contribution was not significant till 2013. Welfare gain for China will be substantially higher than that of India and Bangladesh. Based on above findings, it may be concluded that a BCIM FTA would benefit the trade of energy sector products in this region and all the concerned countries would likely to gain through this process.

\section{References}

1. AmitaBatra and Zeba Khan (2005) 'Revealed comparative advantage: an analysis for India and China' working paper no 168 of Indian Council for research on international economic relation (ICRIER)

2. Arpita Mukherjee and RamneetGoswami, 2009 'Trade in energy services: GATS and India, ICRIER. www.icrier.org/page. asp?MenuID=24\&SubCatId $=175 \ldots 2$ 49.

3. Bhattacharyya S C (2011)‘Energy Economics: Concepts, Issues Markets and Governance, Springer, UK

4. Bhoothalingam, Ravi. 2013. China and its Peripheries: Beijing and the BCIM. Institute of Peace and Conflict Studies (IPCS), New Delhi, Issue BriefNo. 216 (May 2013): IB216- Bhoothalingam-ChinaPeripheryBCIM.pdf.

5. By Rene Vossenaar and VeenaJha, 2010 'Technology mapping of the Renewable Energy, buildings, and transport sectors: Policy drivers and international trade aspects' ICTSD Programme on Trade and Environment.

6. Cossy, M. (2011). "Environmental Services and the General Agreement on Trade in Services (GATS): Legal Issues and Negotiating Stakes at the WTO" in Harmann, C., and Terhechite, J.P. (eds) European Yearbook of International Economic Law, Springer, New York.

7. Deloitte (2013), 'securing tomorrow's energy today: policy and recommendation' in long term Energy Security perspective.
8. Export-Import (Exim) Bank of India (2011), New Renewable Energy in India: Harnessing the Potential, Occasional paper 143

9. He Yaohua, cited in Ravni Thakur, "The Chinese Perspectives on the Kunming Initiative (BCIM): A Review of Recently Published Literatures," p. 2. www.ceniseas.org/newasia/ravnipaper.doc.

10. Hubler and Keller 2009 'Energy saving via FDI: Empirical evidence from developing countries in environment and development economy' Cambridge university press.

11. Kim, J. A. (2011). "Facilitating Trade in Services Complementary to Climate friendly Technologies,'ICTSD: Geneva, Switzerland.

12. Kishan S Rana and Patricia Uberoi (2012), Indian North East states The BCIM forum and Regional Integration in Institute of Chinese Studies(ICS)

13. Kyoko Inoue, Mayumi Murayama, M. Rahmattulah, Centre for Bhutan Studies, Sub-regional Relations in the Eastern South Asia: With Special Focus on Bangladesh and Bhutan (Tokyo: IDE-th. p. 63; In the 5th BCIM JETRO, 2004) www.ide.go.jp/English/publish/Jrp/pdf/jrp_32_sec1.pdf conference held in Kunming.

14. LaishramRajen Singh, the Kunming Initiative: Prospects for Sub-regional Cooperation.

15. Liu Xuejun(2014) BCIM Energy Cooperation strategic importance, real problems and possible solution and $\mathrm{M}$. Rahmatullah (2011) strengthening regional transport connectivity and shipping energy cooperation among BCIM countries in South East Asian South Asian studies(SEASAS)

16. Mohammad MasudurRahman (2011), Trade and Investment Potential among BCIM Countries Prospects for a Dynamic Growth Quadrangle, Korea Institute for International Economic Policy (KIEP) scholars paper series,

17. MustafizurRahman, HabiburRahman\&Wasel Bin Shada, 2007 'BCIM economic cooperation: prospects and challenges' Centre for Policy Dialogue (CPD) Bangladesh.www.cpd.org.bd/pub_attach/op64.pdf

18. Peng, Zhihui. "Strengthen Transport Cooperation for Mutual Economic development," Paper presented at the 5 th BCIM conference held in Kunming, December 22, 2004.

19. Plummer, Cheong and Hamanaka (2010) 'Methodology for impact assessment of free trade agreement' for the researchers and policy makers.

20. Plummer, Cheong and Hamanaka, 2010, 'Methodology for impact assessment of FTA' ADB working paper series.

21. Prabir De (Oct, 2011) Expansion of North East India's trade and investment with Bangladesh and Myanmar- An assessment of opportunity and constrains by RIS, Ministry of Development of N.E Region and N.E Council. www.mdoner.gov.in/sites/.../RIS_Border_Trade_Report_ \%20final.pdf

22. Proceedings of the Eleventh BCIM Forum, available on the website of the Centre for Policy Dialogue, Dhaka, at: www.cpd.org.bd/11_BCIM/11_BCIM.html; also the summary report on the meeting available on the website of the Institute of Chinese Studies at: www.icsin.org.

23. Prof.Mahendra P. Lama (2010) "Cooperation in the BCIM Region: Rethinking Opportunities and Newer Approaches" 
24. Rahman et al (2007), "BCIM Economic Cooperation: Prospects and Challenges", Centre for Policy Dialogue Occasional Paper No. 64.

25. Ray, Haraprasad. 2003. North East India's Place in IndiaChina Relations and Its future Role in India's Economy. Kolkata: Institute of Historical Studies.

26. Report of the India-China Joint Study Group on Comprehensive Trade and Economic cooperation, www.mea.gov.in.pdf

27. Report of UN ESCAP, 2002, United Nations Economic and Social Commission for Asia and the Pacific (ESCAP). Asia-Pacific Development journal vol. 9, No1

28. Sun, Shihai. "China and India: Competition or Cooperation," www.asiapacific.ca/pastsummits/apsummit2004/speakers /s_shihai_speech2004/s_sh hai_speech2004.pdf.

29. Ari Kokka, Thomas Matha, 2005, Factor Endowments, Country Size, and Trade and Liberalization: The Effects on Structure of Trade and Industry, University of East Anglia, School of Economic and Social Studies, England.

30. The Kunming Initiative for a Growth Quadrangle between China, India, Myanmar and Bangladesh, August 14-17, 1999, China Report, vol. 36, no. 3, 2000; P. V Indiresan, "Regional Cooperation: Kunming Initiative," Frontline, vol. 17, April 01-14, 2000.

31. Trade statistic in policy making -A commonly use of trade indices and indicator of APTIAD. 